\title{
Accidents to children: the doctor's role. Education or environmental change?
}

\author{
J R Sibert
}

Accidents are the most common cause of death in children in Britain. Six hundred and eighty eight children died in England and Wales in 1987. ${ }^{1}$ They also cause significant handicap and suffering to children. Less serious accidents are very common in childhood with one fifth of the child population attending the accident and emergency department in a year. ${ }^{2}$ The prevention of accidents to children is therefore being increasingly recognised as an important public health problem. ${ }^{3}$ Doctors who treat children and see the effects of their accidents are in a unique position in society not only to diagnose child abuse but also to alert the community of the problem of childhood accidents and to take action to prevent accidents. What is more difficult is how this is to be achieved.

\section{Education or environment?}

It is very tempting to think that all is needed is to alert the public to the dangers of accidents to children by education campaigns. The evidence that these are effective is unconvincing. A programme directed at the parents of children to prevent home accidents (the Rockland County study) made no difference in accident rates between control and target families. ${ }^{4}$ There was little evidence that the 'play it safe television programmes' made any impact on accident rates in children. ${ }^{5}$ An education campaign with posters and literature in Cardiff only sensitised the population to trivial accidents. ${ }^{6}$ Education campaigns may be ineffective because psychosocial stress is involved in the aetiology of many childhood accidents and parents are unlikely to remember safety propaganda at these times. Stress has been found to be related to road traffic accidents, ${ }^{7}$ accidental childhood poisoning in children, ${ }^{8}$ and to accidents as a whole. ${ }^{9}$

It is also tempting to look on accidents to children as a whole and think of general solutions to the problem. All the evidence points to the fact that accidents to children have been prevented by looking at an individual type of accident, looking at the detailed epidemiology of that accident, and evaluating a solution before its widespread introduction. In almost all the cases where accident prevention solutions have been shown to be effective those solutions have been ones that involve environmental change. Examples of environmental solutions that have been successful in preventing accidents to children include flame proofing nightdresses, fencing private swimming pools, car safety seats, smoke alarms, and child resistant containers in preventing accidental child poisoning.

\section{Preventing accidental child poisoning}

Accidental child poisoning is also an example where a single accident problem has been looked at in a methodological way and has been prevented by an environmental solution. The epidemiology has been studied and it has been found that pyschosocial stress is important in its aetiology. ${ }^{810}$ Education campaigns have been evaluated and found to be ineffective. ${ }^{11} 12$ The environmental solution of child resistant containers was first suggested in 1959 by Dr Jay Arena in Durham, North Carolina. ${ }^{13}$ These containers were evaluated in a community in the United States by Scherz where poisoning cases were reduced from 147 to 17 cases per year by the use of child resistant closures. After this success they were introduced for aspirin preparations and reduced poisoning episodes by approximately $50 \%$ in the United States ${ }^{15}$ and $75 \%$ in Britain. ${ }^{16}$

What can doctors and other health care professionals do?

Although education campaigns may not be effective there is much that can be done to prevent accidents to children. In a study in Newcastle, Colver and his colleagues found that health visitors visiting the home giving specific attention to accident prevention can make differences in the way that families behave, in particular with regard to the installation of safety equipment. ${ }^{17}$ The introduction of a child surveillance programme by general practitioners and health visitors ${ }^{18}$ provides an ideal opportunity to make the home and the child's surroundings safer by environmental change.

Doctors see the effects of accidents and have a unique role in influencing the community on child safety. They cannot act alone in accident prevention and many other professionals such as architects, traffic engineers, and fire safety officers need to be involved as well as health professionals. On a national basis the Child Accident Prevention Trust has brought these disciplines together. Locally child accident committees have been shown to be effective in preventing accidents by a coordinated multidisciplinary approach. ${ }^{19}$ Doctors, in particular the 
consultant paediatrician (community child health), should play their part in the formation of these committees.

Solutions for preventing individual accidents to children

PEDESTRIAN ROAD TRAFFIC ACCIDENTS

Road traffic accidents remain a major challenge in accident prevention in childhood. Boys between 5 and 8 years are at maximum risk. Children under the age of 8 years are not able to estimate the speed or dangers of traffic, ${ }^{20}$ nor to foresee dangerous situations, ${ }^{21}$ and parents may overestimate the ability of their children to handle traffic and let them go out on the road unsupervised. Sharples and her colleagues looked at deaths from head injury in the Northern region and found that $72 \%$ of these deaths occurred between $3 \mathrm{pm}$ and $9 \mathrm{pm}$ and mostly to boys playing after school. ${ }^{22}$

Safety and traffic education are therefore not likely to prevent road traffic accidents by themselves. Pease and Preston found that kerb drill was not perceived by young children to detect traffic and was thought sufficient by itself to ward off the dangers of the road. ${ }^{23}$ Firth found that 'adequate explanations of exactly what is involved in road safety given by very few children'. ${ }^{24}$ In Britain it has been suggested that the Green Cross Code prevented accidents when it was introduced but careful analysis of the figures suggests this was not the case. ${ }^{25}$

The most important means of preventing these pedestrian road traffic accidents is by modification of the environment. This can be done by redesigning residential areas to give priority to pedestrians and to separate them from traffic. The speed of traffic can be reduced by speed bumps and safe crossings can be provided. Sensitive schemes such as the 'Woonerf, ${ }^{26}$ an area in which the residential function clearly predominates over any provisions for traffic in the Netherlands, are good examples of what can be done. The provision of play areas and generally improving the environment will reduce the number of children on dangerous streets.

\section{ACCIDENTS TO CHILD PASSENGERS IN CARS}

There is good evidence that seat belts are effective in preventing death and serious injury and since 1983, when legislation was introduced compelling the wearing of seat belts in front seats of vehicles, serious injuries have fallen as much as $20 \%$. There is good evidence also that child restraint systems also prevent injury and death. The Transport and Road Research Laboratory found that no child died in a two year period when in a restraint whereas 264 non-restrained children were killed in that time. ${ }^{27}$ Scherz found in Washington State USA that serious injuries were much less common in restrained children than non-restrained children. ${ }^{28}$ Encouraging parents to obey the law and carry children in cars in approved restraints should form part of a child surveillance programme. The concept first ride-safe ride is much to be encouraged.

\section{BICYCLE ACCIDENTS}

There are factors in bicycle design that are important to safety. For example the high rise bicycle that was introduced into Britain in the late 1960 s and early 1970 s, had features such as the centre of gravity behind the back wheel when the rider was mounted that made it more dangerous than standard models. ${ }^{29}$ Improvements in design have now meant that this model has been superseded. Parents should be encouraged to give thought to the type of bicycle that they buy for their child and to the proper maintenance of chain, gear, and brakes. Bicycle training for children also seems sensible.

The majority of the severe injuries that children have are those to the head and a boy has a one in 80 chance of having a bicycle head injury severe enough for admission to hospital in his childhood. ${ }^{30}$ Cycle helmets are a logical solution to this problem. At present, this type of protection is not easily available and is expensive. A first step in their more widespread use would be to ensure that they are cheap and easy to buy. This is being encouraged in some areas at present. ${ }^{31}$ A new British standard is now available.

\section{BURNS AND SCALDS}

The problem of nightdress fires causing horrific burns to girls was a major problem in the immediate postwar years. The environmental solution of fire retardant nightwear and probably also the reduction of open fires has reduced this problem to a small one.

On the other hand the majority of deaths from burns in children are due to house fires and these house fires remain a major problem with nearly 100 children dying in England and Wales in a year. ${ }^{1}$ These house fires are particularly common in poorer families and many of them are due to the inflammability of upholstered foam furniture. The change to fire retardant foam early in 1988 is much to be welcomed as a clearly advantageous environmental measure but it will take some time for all the dangerous furniture to be out of homes.

Education campaigns have been shown to be ineffective in influencing behaviour regarding fire safety. ${ }^{32}$ Smoke alarms have been shown to be effective in reducing problems from house fires ${ }^{33}$ and now should be in every home. Encouraging families with children to have smoke alarms fitted should be an important part of a child surveillance programme.

Within the home many children scald themselves from kettles. The use of curled flexes to prevent flexes hanging over work surfaces so that they can easily be pulled by children is a simple environmental measure that can prevent some scald accidents to children. Similarly many children scald themselves from pulling on saucepan handles overhanging on cookers. This can be prevented by cooker guards or by placing other kitchen units beside cookers.

\section{DROWNING}

Drowning remains a significant problem in 
childhood with approximately 50 children dying each year in England and Wales. ${ }^{1}$ Research has suggested that supervision within public pools has reduced deaths in a significant number and in 1988 no children died in a public pool in Britain. ${ }^{34}$ On the other hand drowning in private pools and garden ponds remains a major problem. Research in Australia by Pearn and Nixon has suggested that drowning is 10 times more common in cities without fencing to private pools by regulation than those that have regulations with fencing. ${ }^{35}$ Drowning in the bath in very young children remains a problem. A child surveillance programme should include making certain that garden ponds are fenced, drained, or have a metal mesh under the surface, make certain that garden swimming pools are fenced, and emphasise the dangers of leaving young children in a bath unattended.

\section{PLAYGROUND INJURIES}

The challenge of playground accidents was highlighted by Illingworth et al. ${ }^{36}$ There are clear design issues which are important. ${ }^{37}$ Surfaces should be impact absorbing such as bark or special rubber tiles and not be hard like concrete. Slides should go down natural slopes and not have ladders to climb. Roundabouts should not be designed so children's feet can be trapped underneath. Swings should have impact absorbing seats and be fenced to prevent children running across them. Climbing frames should be built to encourage horizontal not vertical play.

\section{GLASS ACCIDENTS}

The problem of glass accidents was highlighted by Jackson, ${ }^{38}$ and significant numbers of children are injured from falling through glass. This may result in haemorrhage and nerve damage. These injuries can be prevented by the use of safety glass, which is laminated, or by fitting a safety film on existing glass to make it less likely to shatter on impact. Safety glass has now to be used in doors in new houses because of building regulations. Advising on glass within the home should be part of a child surveillance programme.

\section{FALLS}

Falls are also the commonest cause of presentation to the accident and emergency department ${ }^{2}$ and cause a significant number of deaths in childhood. ${ }^{39}$ They have a varied aetiology.

Falls can be from one level to another. Children may be dropped, fall from furniture, fall down the stairs, fall from toys, and fall from windows. Falls downstairs are a particular problem for toddlers. Much can be done to prevent them by better stair design. Stair gates are valuable, especially for the busy mother in poorly designed properties. Their use can be encouraged by the health visitor and should be part of a child surveillance programme. Open stairs with wide gaps between balustrades may be fine aesthetically but dangerous for young children. In 1985 building regulations were changed to make certain that a $100 \mathrm{~mm}$ sphere could not be passed through any opening or guarding to a flight of stairs.

The danger of falls from baby walkers has been highlighted and they can no longer be advised for children's use. ${ }^{40}$ Poor window catches and design cause a number of accidents, particularly in high rise flats. The introduction of safe catches or window guards will reduce these accidents. Indeed, in New York City a programme providing free window, guards ('the children can't fly program'), has been successful in preventing window falls in a poor area of New York. ${ }^{41}$

Checklist for doctors and health visitors to prevent accidents as part of a programme of child surveillance

- Discover particular accident problems in the district

- Establish links with councillors, parents, organisations, etc

- Deal with each accident individually.

TO PREVENT ROAD TRAFFIC ACCIDENTS

- Encourage parents of children 8 years old or less to take them to school

- Encourage use of play areas for children

- Encourage local action in dealing with dangerous road situations-particularly near schools

- Encourage use of car safety seats for children. Try and make 'first ride-safe ride'

- Encourage the use of bicycle safety helmets

- Encourage parents to let their children attend bicycle riding instruction and to maintain the bicycles adequately.

TO PREVENT BURNS AND SCALDS

- Encourage disposal of dangerous foam furniture

- Encourage use of smoke alarms

- Discourage open fires. If they have to be used use fireguards

- Emphasise dangers of hot liquids

- Place kitchen units on either side of cooker or fit cooker guard

- Use coiled flex electric kettles

- Encourage safe use of fireworks.

TO PREVENT DROWNING

- Fence private pools. Take care with pool cover design. Drain pools in winter

- Supervise swimming adequately especially to non-municipal public pools, lakes, and rivers

- Teach children to swim

- Advise parents regarding dangers of young children in baths and in garden ponds

- Fence, grid, or remove garden ponds

- Use life jackets and buoyancy aids for children in boats.

TO PREVENT RECREATIONAL ACCIDENTS

- Find playgrounds in the district and check on design and surfaces. Investigate any playground injuries 
- Influence safe design with local councils

- Be aware of dangers of dogs (as part of health visitor's accident prevention package)

- Keep dogs out of playgrounds

- Supervise sporting activities in children

- Encourage use of head protection for horse riding as British standard (BS 6473).

\section{TO PREVENT 'ARCHITECTURAL' ACCIDENTS} AND FALLS

- Check design of stairs for child safety

- Advise stair gates to families with toddlers in house

- Advise against baby walkers

- Check window and balcony design for child safety. Advise catches if necessary

- Advise safety glass or safety film for low level glazing.

TO PREVENT ACCIDENTAL POISONING

- Encourage use of child resistant containers by pharmacists

- Encourage storage of medicines and household products away from children

- Discourage prescribing of quinine and barbiturates, etc.

1 Office of Population Censuses and Surveys. Deaths by accidents and violence. London: OPCS, 1988. (Quarterly Monitors DH4 Series.

2 Sibert JR, Maddocks GB, Brown M. Childhood accidentsan endemic of epidemic proportions. Arch Dis Child 1981; 56:225-7.

3 Child Accident Prevention Trust. Basic principles of child accident prevention. London: CAPT, 1989.

4 Schlesinger ER, Dickson DG, Westaby J, Logrillo VM, Maiwald AA. A controlled study of health education in accident prevention: the Rockland County child injury project. Am F Dis Child 1966;111:490-6.

5 Sibert JR, Williams H. Medicine and the media. BMF 1983; 286:1893.

6 Minchom P, Sibert JR. Does health education prevent childhood accidents. Postgrad Med f 1984;60:260-2.

7 Backett EM, Johnston AM. Social pattern of road accidents to childhood. Some characteristics of vunerable families. to childhood. Some

8 Sibert JR. Stress in families of children who have ingested poisons. $B M \mathcal{B}$ 1975;ii:87-9.

Brown GW, Davidson S. Social class, psychiatric disorder of mother and accidents to children. Lancet 1978;i:378-81.

10 Bithoney WG, Snyder J, Michalek J, Newberger EH Childhood ingestations as symptoms of family distress. $\mathrm{Am}$ f Dis Child 1986;139:456-9.

11 Harris DW, Karindiker DS, Spencer MG, Leach RH, Bower AC, Mander GA. Returned medicines campaign in Birmingham 1977. Lancet 1979;ii:599.

12 Ferguson DM, Horwood LJ, Beautrais MA, Shannon FT.
A controlled trial of a poison prevention method. Pediatrics 1982;69:515.

13 Arena JM. Safety closure caps. JAMA 1959;169:1187-8.

14 Scherz RG. Prevention of childhood poisoning. Pediatr Clin North Am 1970;17:713.

15 Clarke A, Walton WW. Effect of safety packaging on aspirin ingestion by children. Pediatrics 1979;63:687-93.

16 Sibert JR, Craft AW, Jackson RH. Child resistant packaging and accidental child poisoning. Lancet 1977;ii:289-90.

17 Colver AF, Hutchinson PJ, Judson EC. Promoting children's home safety. $B M \mathcal{F}$ 1982;285:1177-80.

18 Hall DMB, ed. Health for all children. Oxford: Oxford University Press, 1989.

19 Schelp L. Community intervention and changes in accident pattern in a rural Swedish municipality. Health Promotion 1979;2:109-25.

20 Howarth CI, Routledge DA, Repetto-Wright R. An analysis of road accidents involving child pedestrians. Ergonomics 1974;17:319-30.

21 Kohler L, Ljungblom B-A. Child development and traffic behaviour. Traffic and children's health. Stockholm: Nordic School of Public Health, 1987.

22 Sharples PM, Storey A, Anysley Green A, Eyre JA. Avoidable factors contributing to death of children with Avoidable factors contributing to deat
head injury. $B M F$ 1990;300:87-91.

23 Pease K, Preston B. Road safety education for young children. Br $\mathcal{F}$ Educ Psychol 1967;37:305-13.

24 Firth DE. Roads and road saftey-descriptions given by 400 children. Crowthorne, Berkshire: Transport and Road Research Laboratory, 1975. (TRRL Supplementary Repor 138UC.)

25 Grayson GB. The identification of training objectives: what shall we tell the children? Accid Anal Prev 1981;13:169-73.

26 Royal Dutch Touring Club. Woonerf. The Hague, Netherlands: Royal Dutch Touring Club, 1977. (Available from: the Royal Dutch Touring Club, PO Box 93200, The Hague, Netherlands.)

27 Transport and Road Research Laboratory. The protection of children in cars. Crowthorne, Berkshire: TRRL, 1974. (Leaflet 345.)

28 Scherz RG. Restraint systems for the prevention of injury to children in automobile accidents. Am $\mathcal{F}$ Public Health 1976; children

29 Sibert JR, Newcombe RG. Bicycle injuries in childhood. $B M \mathcal{F}$ 1977;i:613-4.

30 Clarke AJ, Sibert JR. Why child cyclists should wear helmets. Practitioner 1986;230:513-4.

31 Walker A. Cycling in cities. BMF 1990;301:80.

32 McCabe $M$, Moore $H$. Is national fire safety week a waste of time? Fire Prevẹntion 1990;232:12-4.

33 US Fire Administration. An evaluation of residential smok detectors under actual field conditions. Final Report EMW-C-002. Washington DC: US Fire Administration 1980.

34 Kemp A, Sibert JR. Drowning and near drowning in children. Proceedings of the Annual Meeting of the British Paediatric Association. Warwick, April 1990.

35 Pearn JH, Nixon J. Are swimming pools becoming more dangerous? Med $\mathcal{F}$ Aust 1977;2:702-4.

36 Illingworth CW, Brennan P, Jay A, Al-Rawif ER, Collier M. 200 injuries caused by playground equipment. $B M \mathcal{F} 1975$; iv:332-4.

37 National Playing Fields Association. Playground management and safety. London: NPFA, 1989.

38 Jackson RH. Lacerations from glass in childhood. BMF 1981;283:1310-2

39 Nixon J, Jackson H, Hayes M. An analysis of childhood falls involving stairs and bannisters. London: Consumer Safety Unit, Department of Trade and Industry, 1987.

40 Glendill DNS, Robson WV, Cudmore RE, Tavistock RR. Baby walkers-time to take a stand. Arch Dis Child 1987; 62:491-4.

41 Speyel CM, Linderman F. Children can't fly. A program to prevent mobility and mortality from window falls. $A m$ f Public Health 1977;68:1143-7. 